\title{
Antifouling Effect of Bioactive Compounds from Marine Sponge Acanthella elongata and Different Species of Bacterial Film on Larval Attachment of Balanus amphitrite (Cirripedia, Crustacea)
}

\author{
Viswambaran Ganapiriya, Athisuyambulingam Maharajan* and Pothiappan Kumarasamy \\ $P G$ \& Research Department of Zoology; Khadir Mohideen College; Adirampattinam, 614701; Thanjavur Dist; \\ Tamil Nadu - India
}

\begin{abstract}
The antifouling activity of bioactive compounds from marine sponge Acanthella elongata (Dendy) and five species of bacterial biofilm were studied. Larvae of Balanus amphitrite (Cyprids and nauplii) were used to monitor the settlement inhibition and the extent to which inhibition was due to toxicity. The crude extract and partially purified fractions of A.elongata showed significant inhibition over the settlement individually, and with the interaction of bacterial species. No bacterial film stimulated the barnacle settlement. The high but variable levels of antifouling activity in combination with less amount of toxicity showed the potential of these metabolites in environmentallyfriendly antifouling preparations.
\end{abstract}

Key words: Biofouling, bacterial film, bacteria, Barnacles, Cyprids, B. amphitrite

\section{INTRODUCTION}

Any natural or man-made substrates in the marine environment are quickly subject to biofouling, which is due to different species of micro and macro organisms (Railkin 2004). Biofouling causes serious problems for marine industries and navies around the world (Yebra et al. 2004). Marine biofouling is a complex assemblage of organisms on artificial structures comprising micro- as well as macro- foulers and often it has been reported that micro-fouling facilitates macrofouling process (Callow and Callow 2002). New environmental regulations have put restrictions on the use of antifouling biocides in the industrial formulations (Di Landa et al. 2006). Natural products with antifouling activity (or NPAs, Clare
1998) have been isolated from a wide range of sessile marine organisms including gorgonians, sponges, bryozoans, ascidians, algae and sea grasses (Davis et al. 1989; Clare 1996). The development of coatings based on the natural products from marine organisms (de Nys et al. 1995; Rittschof 2000) is a promising alternative to the present antifouling technologies, particularly since the TBT based, and possibly other metal based paints are banned in the global market.

Some marine organisms such as corals, algae, sponges, and ascidians have been shown to produce antifouling substances which in nature maintain them free from undesirable encrusting organisms (Hentschel et al. 2001; Dobretsov and Qian 2002; Harder et al. 2003). The biochemical mechanisms that sponges have developed as a

*Author for correspondence: athimaha@yahoo.co.in 
chemical defense for the growth inhibition of epiphytic micro and macro organisms might comprise a potential alternative for the prevention of biofouling. In this regard, sessile, soft bodied marine organisms maintaining a clean surface were identified as possible sources of natural product antifoulants (NPAs). Sponges, with their rich chemical defense mechanisms are one of the most studied organisms for the isolation of NPAs (Thakur and Anil 2000). Sponges and Octocorals contain a wealth of secondary metabolites (Faulkner 1995; Tilvi et al. 2004). Natural products and their synthetic analogs exhibiting anaesthetic, repellent and settlement inhibition properties, but non-toxic to the non-target organisms, are preferred as potential antifouling agents (Omae 2003). Possible antifouling properties of the compounds isolated from the sponge was first recognized by Bakus et al. (1983). Further studies in this direction have revealed tremendous antifouling potential of some of the bioactive metabolites inherent in the sponges (Clare 1996; Omae 2003; Fusetani 2004; Chambers et al. 2006). Notable among them is polymeric alkylpyridinium salts (Poly-APS), a non-toxic NPA from the sponge Reniera sarai (Kaiser et al. 1998; Fusetane 2004; Turk et al. 2007).

Aggregates of micro organisms adhered to each other and / or to surfaces with a distinctive architecture can be referred to as biofilm. Biofilm develops rapidly on immersed substrate (Wahl, 1989) and have been reported to influence the settlement and metamorphosis of a wide range of marine invertebrate larvae (Wieczorek and Todd 1998). Bacteria (biofilm) can play an important role in controlling the growth of micro-and macroalgae. It has been reported that some bacteria in the genera Flavobacterium, Cytophaga, Alteromonas Pseudomonas and Pseudoalteromonas and their excretion products are capable of inhibiting the growth of diatoms and microalgae which are common in harmful phytoplankton blooms (Lee et al. 2000; Burgess et al. 2003).

Biofilm can enhance (Kirchman et al. 1982; Lau and Qian 2001) or inhibit larval settlement of marine invertebrates (Rodriguez et al. 1993; Egan et al. 2000; 2001; Dobrestove and Qian 2002). Chemical compounds produced by the bacteria and diatoms, as well as biofilms of live microorganisms can lead to the disruption of biofilm, formation and / or prevention of the epibiosis, and therefore, they may be useful for the biotechnological development of an "environmentally- friendly" protection against the marine biofouling (Clare et al. 1992; Armstrong et al. 2000).

In the present study, an attempt has been made to investigate the antifouling potential of marine sponge A. elongata and bacterial film interaction against the settlement of cyprid larvae of $B$. amphitrite.

\section{MATERIALS AND METHODS}

\section{Collection and extraction of marine sponge}

The marine sponge Acanthella elongata (Dendy) was collected from the Tuticorin harbor, South east coast of India. Methanol and Methylene chloride extract of the sponge was prepared as described by Rittschof et al. (1986). The organic extract was fractionated by the gradient vacuum liquid chromatography (VLC) on silica gel. The different solvent systems used were: Hexane: Chloroform 3:1, Hexane: Chloroform 1:1, Chloroform $100 \mathrm{ml}$, Chloroform: Ethyl acetate 1:1, Ethyl acetate $100 \mathrm{ml}$, Methanal $100 \mathrm{ml}$. Column was packed in scintillation flask with silica gel normal phase 10 micron \pm 4 micron. Column was activated with $50-75 \mathrm{ml}$ hexane; 50 $\mathrm{ml}$ of the first solvent was added before the crude extract was poured on to the column and pulled it down on to the silica gel by vacuum. Eight fractions were obtained and pooled to 1-3 fractions with increasing numbers, indicating the increased polarity of the fraction.

\section{Collection and rearing of barnacle cyprid larvae}

Barnacles B.amphitrite Darwin wascollected from Tuticorin (Gulf of Mannar, South east coast of India). Adult barnacles released the first stage nauplii and the positively phototrophic nauplii were collected in the filtered and sterilized sea water containing antibiotics. The young nauplii were fed daily with microalgae Dunaliella tertiolecta and Nitzschia sp. at a density of 30,000 cells $/ \mathrm{ml}$. The rearing vessels were kept in $28^{\circ} \mathrm{C}$ and 15:9h (L: D) photoperiod.

\section{Settlement Assay}

Barnacle settlement assays were undertaken using the method by Rittschof et al. (1985). Briefly, 
Falcon $50 \times 9 \mathrm{~mm}$ plastic polystyrene dishes were filled with $5.0 \mathrm{ml}$ of filtered sea water at salinity of 33-35 ppt into which 3-day old cyprid were added. The test compounds were added in various concentrations. Controls were represented by those dishes in which no test compounds were added. After incubation at $28^{\circ} \mathrm{C}$ for $9 \mathrm{~h}$, the dishes were examined under the dissecting microscope to determine if there was any mortality. The larvae were then killed with few drops of $10 \%$ formalin and attached and unattached larvae were counted. Settlement data were expressed as the percentage of the larvae attached to the bottom of the dish. Effective concentration $\left(\mathrm{EC}_{50}\right)$ values were then calculated.

\section{Naupliar toxicity assay}

For the toxicity studies, static bioassay was conducted under the laboratory conditions. Thirty newly hatched nauplii were introduced in to the polystyrene dishes containing test compounds at various concentrations. One control and six test concentrations with triplicates were maintained. After $24 \mathrm{~h}$, dead nauplii were counted and median lethal concentration $\left(\mathrm{LC}_{50}\right)$ values were calculated.

\section{Preparation of Bacterial biofilm and Settlement assay}

Single species bacterial films were prepared by incubating the bacterial strains (Avelin Mary et al. 1993) in Zobell's Marine Broth (Difco2216). Incubation solutions were transferred and the dishes in which incubation had occurred were rinsed with filtered sea water and filled with 5.0 $\mathrm{ml}$ of fresh filtered and sterilized sea water, used in settlement assays. The poly styrene dishes were filled with the extracts and VLC purified fractions at the concentrations of $\mathrm{EC}_{50}$ values. The cyprid larvae (100-150) were placed in three replicate dishes composed of films of five different bacterial species, viz., Aeromonas sp., Alcaligenes sp., Flavobacterium sp., Pseudomonas sp., and Vibrio $s p$., and incubated for $24 \mathrm{~h}$ at $28^{\circ} \mathrm{C}$ and $15: 9 \mathrm{~h}$ (L:D) photoperiod. Percent settlement rate was calculated.

\section{RESULTS}

\section{Cyprid Settlement Inhibition Assay}

The crude methylene chloride extract of $A$. elongata and three VLC fractions significantly inhibited the cyprid larval settlement (t-test $\mathrm{P}<0.05$ with four degrees of freedom) than the control. The $\mathrm{EC}_{50}$ value of the crude extract $(0.13 \mathrm{mg} / \mathrm{ml})$ was lower than all the fractions (Fig.1). VLC fraction 1 showed $\mathrm{EC}_{50}$ value of $1.01 \mathrm{mg} / \mathrm{ml}$ (Fig.2) and VLC fraction 3 showed $\mathrm{EC}_{50}$ value of $0.99 \mathrm{mg} / \mathrm{ml}$ (Fig.4) which significantly inhibited the larval settlement. At higher concentration $(10 \mathrm{mg} / \mathrm{ml})$, the crude extract and all the three VLC fractions of $A$ elongata strongly inhibited the larval settlement (Fig.1, 2, 3, and 4).

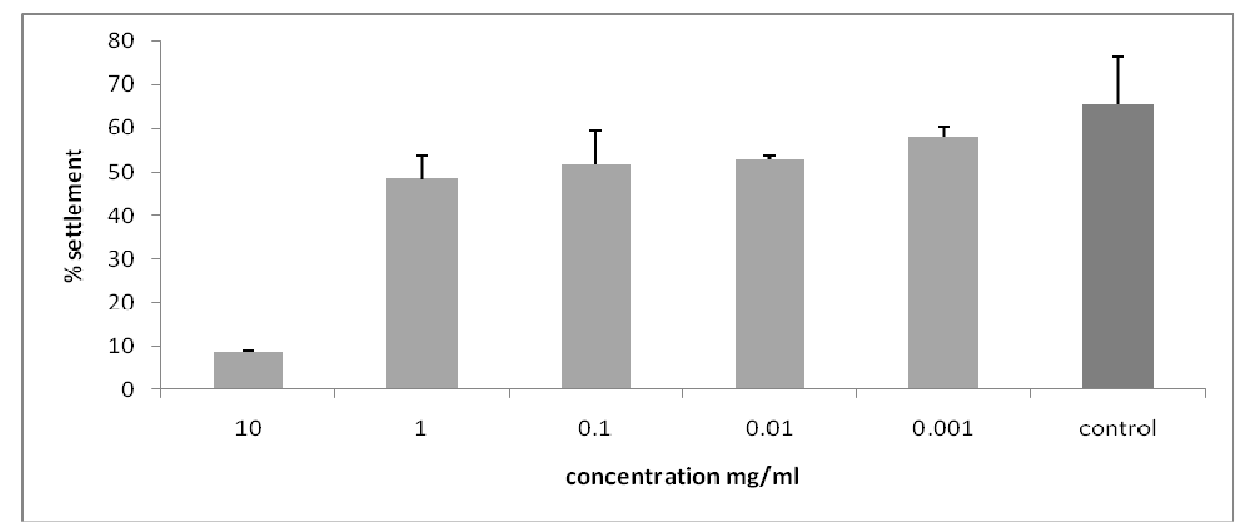

Figure 1 - Barnacle settlement assay on methylene chloride extract of A.elongata at different concentrations. 


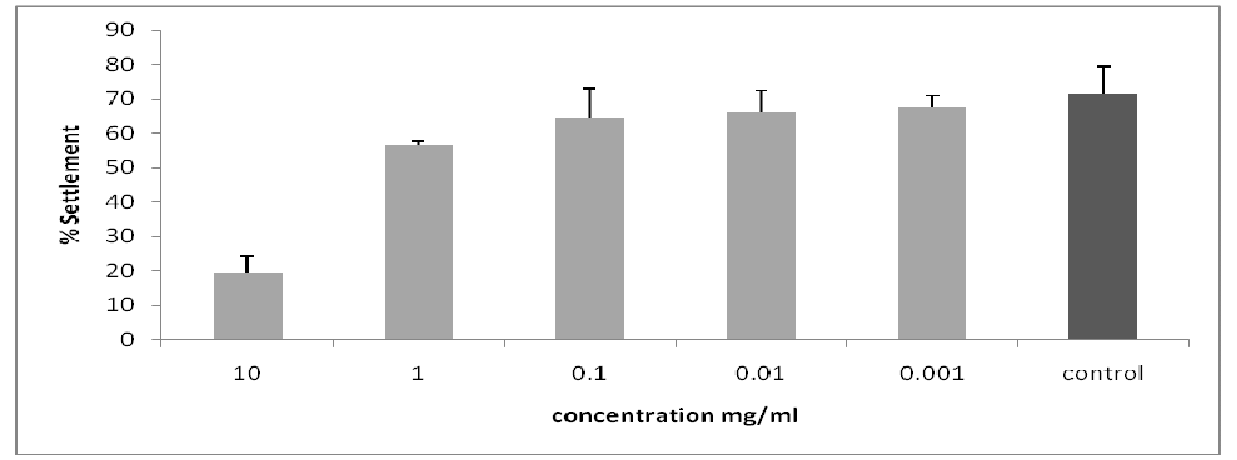

Figure 2 - Barnacle settlement assay onVLC1 of A.elongata at different concentrations.

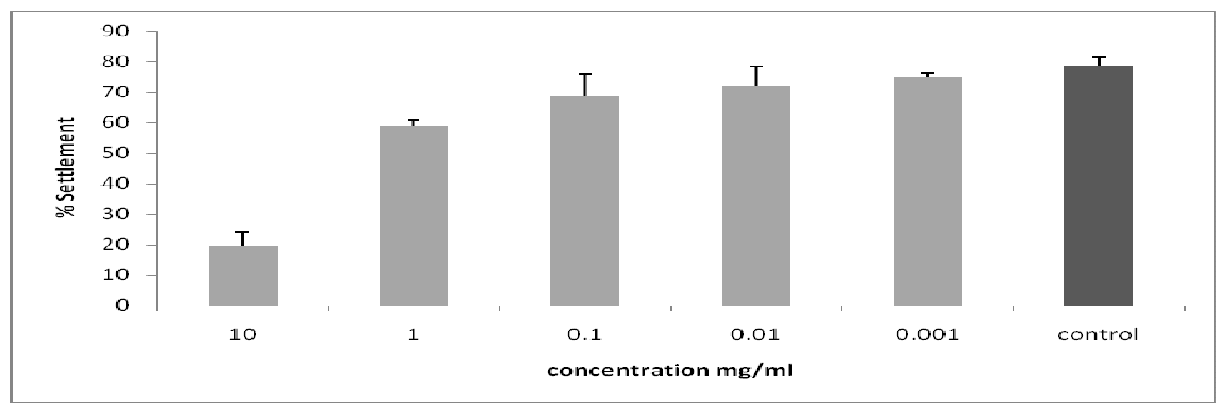

Figure 3 - Barnacle settlement assay onVLC2 of A.elongata at different concentrations.

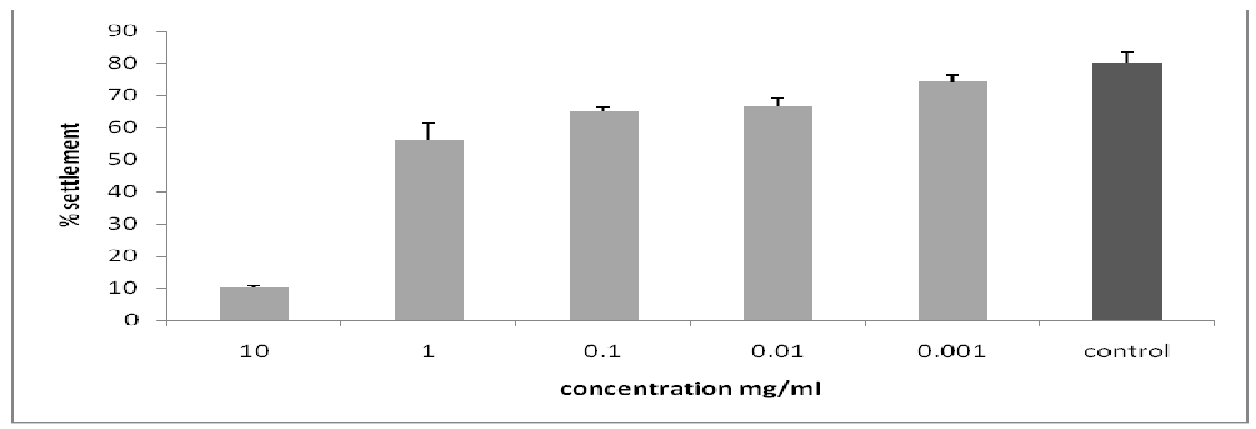

Figure 4 - Barnacle settlement assay onVLC3 of A.elongata at different concentrations.

\section{Naupliar Toxicity Assay}

The VLC fraction $2\left(\mathrm{LC}_{50}: 0.014 \mathrm{mg} / \mathrm{ml}\right)$ was less toxic to nauplii of $B$. amphitrite than the crude extract and other fractions (Table 1). Except VLC fraction 2, the crude extract and other VLC fractions showed $100 \%$ mortality of nauplii at higher concentrations $(10 \mathrm{mg} / \mathrm{ml})$. At lower concentration $(0.0001 \mathrm{mg} / \mathrm{ml})$, all the fractions and crude extract showed less mortality rate.

Table 1 - Evaluation of anti-settlement and toxicity of crude extract and VLC fractions of A. elongata on larval $B$. amphitrite.

\begin{tabular}{clcc}
\hline S. No & \multicolumn{1}{c}{ Compounds of A.elongata } & $\mathbf{E C}_{\mathbf{5 0}} \mathbf{~ m g / \mathbf { m l }}$ & $\mathbf{L C}_{\mathbf{5 0}} \mathbf{~ m g} \mathbf{m l}$ \\
\hline 1 & Methylene chloride extract (Crude) & 0.13 & 0.005 \\
2 & VLC Fraction 1 (Hexane : Chloroform soluble fraction) & 1.01 & 0.004 \\
3 & VLC Fraction 2 (Chloroform : Ethyl acetate soluble fraction) & 1.24 & 0.014 \\
4 & VLC Fraction 3 (Ethyl acetate : Methanol soluble fraction) & 0.99 & 0.007 \\
\hline
\end{tabular}


Interaction of bacterial film and compounds of A. elongata on cyprid settlement

The crude extract along with Aeromonas $s p$ (3.68\%) was highly potent in inhibiting the settlement of cyprid larvae ( $<<0.001$ with four degrees of freedom). Films of Vibrio sp. (21.34\%) and Pseudomonas sp. (35.44\%) showed inhibitory activity than Alcaligenes $s p$. and Flavobacterium $s p$. on larval settlement (Table 2). With the VLC fraction 3 of A. elongata, all the five species of bacteria strongly inhibited the larval settlement when compared to the extract and other fractions. Alcaligenes sp., with crude extract and three fractions showed less inhibition rate than other bacterial species.

Table 2 - Settlement assay on bacterial film with crude extract and VLC fractions of A. elongate.

\begin{tabular}{|c|c|c|c|c|c|}
\hline \multirow{2}{*}{ S. No. } & \multirow{2}{*}{$\begin{array}{c}\text { Bacterial - species and } \\
\text { control }\end{array}$} & \multicolumn{4}{|c|}{ Percent settlement } \\
\hline & & $\begin{array}{l}\text { Methylene Chloride } \\
\text { Extract of } \text { A. elongata }\end{array}$ & $\begin{array}{l}\text { VLC } 1 \text { of } \\
\text { A. elongata }\end{array}$ & $\begin{array}{l}\text { VLC } 2 \text { of } \\
\text { A. elongata }\end{array}$ & $\begin{array}{c}\text { VLC } 3 \text { of } \\
\text { A. elongata }\end{array}$ \\
\hline 1 & Sea water control & 84.18 & 84.18 & 84.18 & 84.18 \\
\hline 2 & Broth control & 46.67 & 46.67 & 46.67 & 46.67 \\
\hline 3 & Aeromonas sp. & 3.68 & 28.41 & 38.07 & 10.49 \\
\hline 4 & Flavobacterium $s p$. & 45.05 & 44.29 & 53.08 & 30.24 \\
\hline 5 & Pseudomonas sp. & 35.44 & 38.82 & 43.84 & 31.05 \\
\hline 6 & Vibrio sp. & 21.34 & 33.72 & 45.29 & 20.01 \\
\hline 7 & Alcaligenes sp. & 50.41 & 52.07 & 63.39 & 47.37 \\
\hline
\end{tabular}

\section{DISCUSSION}

Biofouling is one of the most serious problems the marine domain currently faces. It has been estimated that the growth of marine fouling organisms costs the shipping and other marine industries over $\$ 6.5$ Billion per year (Bhaduray et al. 2004). Many marine sponges, as well as other benthic organisms, are relatively free of settlement by fouling organisms (Steinberg et al. 2002) due to the production of biogenic compounds. Therefore, the isolation and production of these natural products from marine organisms could be used for the prevention of biofouling.

The antifouling strategy of $A$. elongata was tested in the laboratory on larval settlement. The assays were performed on the crude extract of sponge, as well as in chromatographically separated fractions. The crude methylene chloride extract $\left(\mathrm{EC}_{50}: 0.13\right.$ $\mathrm{mg} / \mathrm{ml}$ ) and partially purified VLC3 ( $\mathrm{EC}_{50}: 0.99$ $\mathrm{mg} / \mathrm{ml}$ ) were highly potent in inhibiting the larval settlement than other VLC fractions. At higher concentration $(10 \mathrm{mg} / \mathrm{ml})$, the settlement rate was decreased. VLC fraction $2\left(\mathrm{EC}_{50} 1.24 \mathrm{mg} / \mathrm{ml}\right)$ showed good anti-settlement activity and at low concentrations, it was less toxic to barnacle larvae with a $\mathrm{LC}_{50}$ value of $0.014 \mathrm{mg} / \mathrm{ml}$.

Ethyl acetate extracts and purified fractions of Lissodendoryx isodictyalis inhibited the settlement of cyprid larvae of barnacle $B$. amphitrite
(Margaret et al. 1990). The crude extract of Leptogorgia virgulata proved to be effective in the field at inhibitory settlement of fouling organisms (Rittschof et al. 1985). Low molecular weight substances from the extract of Renilla reniformis inhibited the settlement of larval $B$. amphitrite. The substances were similar to $B$. amphitrite attachment inhibitors from Leptogorgia virgulata (Rittschof et al., 1988). In agreement with above screening strategies, the crude extract and partially purified VLC fraction 3 of A. elongata were potent inhibitory for the settlement of barnacle cyprid larvae.

Bacteria can play an important role in controlling the growth of micro and macro foulers. In the present study, Aeromonas sp. (3.69\%) and Vibrio $s p .(21.34 \%)$ coated surface along with the crude extract and fractions of $A$. elongata significantly inhibited cyprid larval attachment than polystyrene control $(84.18 \%)$. The crude extracts normally used in these experiments could change the texture of the surface film (Williams 1964). The VLC fraction 3 of A. elongata with Aeromonas $s p$. $(10.49 \%)$ and Vibrio sp. (20.00\%) were significantly different from the sterilized sea water control and broth control $(p<0.001$ with four degrees of freedom).

The present analysis clearly indicated that methylene chloride extract and partially purified fractions of A. elongata along with single species 
bacterial film consistently inhibited barnacle larval settlement than the inhibition of crude extract and VLC fractions of A. elongata alone. Different bacterial film showed different settlement response and these data suggested that along with the crude extract and fractions, the species composition of bacterial film were also important in the larval attachment response. Previous investigators (Maki et al.1988; 1990; 1992; Holmstrom et al. 1992; Avelin Mary et al. 1993) also observed the response of $B$. amphitrite larvae to bacterial films supports the suggestion that bacteria are used as settlement cue. Avelin Mary et al. (1993) tested the effects of the films of individual bacterial strains and found that all Vibrio films and most other bacterial isolates were inhibitory and no bacterial film facilitated cyprid settlement. Biofilm have long been recognized as important modulators for the attachment of invertebrate larvae (Olivier et al. 2000; Lau et al. 2003). In contrast to the present results, certain bacteria had been demonstrated to positively influence the recruitment of a number of marine invertebrate larvae to the surfaces by the production of specific molecules (Maki and Mitchell 1988).

A study carried out by Holmstrom et al. (1996) showed the capacity for the marine bacterial strain Pseudoalteromonas tunicate for inhibiting the growth of common biofouling diatom Amphora $s p$. The field study of Olivier et al. (2000) concluded that the cyprids preferred unfilmed over biofilmed surfaces, which was in accordance with the present analysis. It has been widely reported that many bioactive natural products from marine invertebrate have striking similarities to the metabolites of their associated microorganisms, including bacteria (Proksch et al. 2002). Thus, the present study highlighted the possible role of marine bacteria associated with the sponges in providing an alternative to commercial metalbased antifouling coatings that have been believed to be environmental hazards due to their toxicity.

\section{CONCLUSION}

The settlement inhibitors from A. elongata with single species bacterial film could provide useful insight in to the mechanisms to control the larval settlement. In addition, nontoxic settlement inhibitors such as those found in fraction 2 could be of potential value as alternatives to the ecologically damaging toxic chemicals incorporated into paints to prevent the fouling.

\section{ABBREVIATIONS}

NPA, natural product with antifouling activity; L: D cycle, light dark cycle; $\mathbf{E C}_{\mathbf{5 0}}$, the concentration of the antifouling compound causing settlement inhibition of $50 \%$ experimental organisms; $\mathbf{L C}_{\mathbf{5 0}}$, the concentration of the antifouling compound causing death of $50 \%$ of experimental organisms.

\section{REFERENCES}

Armstrong E, Boyd KG, Burgess JG. Prevention of marine biofouling using natural compounds from marine organisms. Biotech. Ann. Rev. 2000; 6: 221241.

Avelin Mary SR, Vitalina Mary SR ,Rittschof D, Nagabhushanam R. Bacterial barnacle interaction: Potential of using juncellins and antibiotics to alter structure of bacterial communities. J. Chem. Ecol. 1993; 19:2155-2167.

Bakus GJ, Evans T, Mading B, Kourous P. The use of natural and synthetic toxins as shark repellents and antifouling agents. Toxicon 1983; (3): 25-27.

Bhadury P, Wright PC. Exploration of marine algae: Biogenic compounds for potential antifouling applications planta, 2004; 219: 561-578.

Burgess J. Grant, Boyd Kenneth G , Armstrong Evelyn, Jiang Zhong Yan Liming, Berggren, Matz; May Ulrika, Pisacane, Tony, Granmo Akeand Adam S, David R et al. The development of a marine natural product-based antifouling paint. Biofouling.. 19 (1): 197-205.

Callow ME, Callow JA. Marine biofouling: a sticky problem. University of Birmingham, UK Biologist 2002; 49(1).

Chambers LD, Stokes KR, Walsh FC, Wood RJK. Modern approaches to marine antifouling coatings. Surf. Coat Tech. 2006; 201: 3642-3652.

Clare AS. Marine natural product antifoulants: Status and potential. Biofouling. 1996; 9: 211-229.

Clare AS. Towards non-toxic antifouling. J Mar. Biotechnol. 1998; 6: 3-6.

Clare AS, Rittschof D, Costlow JD Jr. Effects of the non-steroidal ecdysone mimic RH 5849 on larval crustaceans, J. Exp. Zool. 1992; 262: 436-440.

Davis AR, Targett NM, Mcconnel OJ Young CM. Epibiosis of marine algae and benthic invertebrates: natural products chemistry and other mechanisms inhibiting settlement and overgrowth. Bioorg. Mar. Chem., 1989; (3): 85-114. 
De Nys R, Steinberg PD, Willesmsen P, Dworjanyn SA, Gabelish CL, King RJ Broad Spectrum effects of secondary metabolites from the red alga Delisea pulchra in antifouling assays. Biofouling. 1995; 8: 259-271.

Di Landa G, Ansanelli G Ciccoli R, Cremisini C. Occurrence of antifouling paint booster biocides in selected harbors and marinas inside the Gulf of Napoli: A preliminary survey. Mar. Pollut. Bull. 2006; 52: 1541-1546.

Dobrestov S, Qian PY Effect of Bacteria associated with the green alga Ulva reticulate on Marine micro and Macrofouling. Biofouling. 2002; 18: 217-228.

Egan S, Thomas T, Holmstrom C, Kjelleberg S. Phylogenetic relationship and antifouling activity of bacterial epiphytes from marine algae Ulva latuca. Environ. Microbiol. 2000; 2: 343-347.

Egan S, James S, Holmstrom C, Kjelleberg S. Inhibition of algal spore germination by the marine bacterium Pseudoalteromonas tunicate. FEMS. Microbiol. Ecol. 2001; 35: 67-73.

Faulkner DJ .(Marine natural Products. Nat. Prod. Rep. 1995; 13: 259-302.

Fusetani N. Biofouling and antifouling. Nat. Prod. Rep. 2004; 21: 94-104.

Harder T, Lau SCK, Dobretsov S, Fang TK, Qian PY A distinctive epibiotic bacterial community on the soft coral Dendronephthya sp. and antibacterial activity of coral tissue extracts suggest a chemical mechanism against bacterial epibiosis. FEMS Microbiol.Ecol.2003; 43 (3): 337-347.

Hentschel,US, Michael W, Michael F, Lars Gernert $\mathrm{C}$, Hacker, J. Isolation and phylogenetic analysis of bacteria with antimicrobial activities from Mediterranean sponges Aplysina aerophoba and Aplysina cavernicola. FEMS Microbiol. Ecol. 2001; 35 (3): 305-312.

Holmstrom C, Rittschof D, Kjelleberg S. Inhibition of settlement of larvae of Balanus amphitrite and Ciona intestinates by a surface - colonizing marine bacterium. Appl. Environ. Microbiol. 1992; 58: 21112115.

Holmstrom C, James S, Egan S Kjelleberg S. Biofouling. 1996; 10: 251-59.

Kaiser A, Billot X, Gateau - Olesker A, Marazano, C, Das BC. Selective Entry to the Dimeric or Oligomeric Pyridinium sponge Marrocycles via Aminopentadienal Derivatives. Possible Biogenetic Relevance with Manazamine Alkaloids. J. Am. Chem. Soc. 1998; 120: 8026- 8034.

Kirchman D, Graham S, Reish D, Mitchell R. Bacteria induce settlement and metamorphosis of Janua (Dexiospira) brasiliensis Grute (Polychaeta:Spirorbidae). J. Exp. Mar. Biol. Ecol. 1982; 56: 153-163.
Lau SCK, Qian PY. Larval settlement in the serpulid polychaete Hydroides elegans (Haswekk) in response to bacterial film; an Investigation of the nature of putative larval settlement cue. Mar. Biol. 2001; 138 (2): 321-328.

Lau SCK, Thiyagarajan V, Qian PY. The bioactivity of bacterial isolates in HongKong water for the inhibition of barnacle (Balanus amphitrite Darwin) settlement. J. Exp. Mar. Biol. Ecol. 2003; 284: 43-60.

Lee,SO, Kato JT, Noboru K, Akio I, Tsukasa M , Atsushi $\mathrm{O}$ Hisao. Involvement of an extracellular protease in algicidal activity of the marine bacterium Pseudo alteromonas sp strain A28. Appl. and Environ. Micro. 2000; 66 (10): 4334-4339.

Maki JS, Mitchell R. L adhesion microbienne aux surfaces etses consequences. In: M.Bianchi, D. Marty, J.C Bertrand, P.Caumette., M.Gauthier eds. Microorganises dans les ecosystems oceaniques. Messon, Peris.1988, 387-409.

Maki JS, Rittschof, D, Mitchell R. Microb. Ecol. 1992; 23: 97-106.

Maki JS, Rittschof D, Costlow JD, Mitchell R. Mar. Biol. 1988; 97:199-206.

Maki JS, Rittschof D, Samuelsson MO Szewzyk U, Kjelleberg S, Costlow JD, Mitchell R (). Bull. Mar. Sci. 1990; 46: 499-511.

Margaret Sears A, Donald Gerhart J, Rittschof D Antifouling Agents from Marine sponge Lissodendoryx isodictyalis Carter, Journal of Chemical Ecology, 1990; 16 (3). Olivier F, Trembky R, Bourget E, Rittschof D. Barnacle settlement: Field experiments on the influence of larval supply, tidal level, biofilm quality and age on Balanus amphitrite cyprids. Mar. Ecol. Prog. Ser. 2000; 199: 185-204.

Omae I. General aspects of tin free antifouling paints Chem. Rev 2003; 103, 3431-3488.

Proksh P, Edrad RA, Ebel R. Drugs from the seascurrent status and microbiological implications. Appl. Microbiol. Biot. 2002; 59: 125-134.

Railkin AI. Marine biofouling: colonization process and defenses. 2004; ISBN 0-8493-1419-4. CRC press.

Rittschof D.. Amer malacol Bull. special Ed.1985; 1: 111-16

Rittschof D. Natural product antifoulants: one perspective on the challenges related to coatings development. Biofouling 2000; (15) 119-127.

Rittschof D, Hooper IR, Costlow JD. Settlement inhibition of marine invertebrate larvae.comparison of sensitivities of bryozoans and barnacle larvae. In: Marine Biodeterioration, edited by MF Thompson et al., Oxford and IBH,New Delhi, 1988 pp. 151-163.

Rittschof D, Hooper IR, Branscomb ES, Costlow JD. Inhibition of barnacle settlement and behaviour of natural products from whip corals, Leptogorgia virgulata (Lamarck 1815), J.Chem.Ecol.1985; (11): 551-563. 
Rittschof D, Maki J, Mitchell R, Costlow JD. Ion and neuropharmacological studies of barnacle settlement. Neth. J. Sea Res.1986; (20): 269-275.

Rodriguez SR, Ojeda FP, Inestrosa NC. Settlement of benthic marine invertebrates. Mar. Ecol. Prog. Ser. 1993; 97: 193-207.

Steinberg PD, De Nys R., Kjelleberg S. Chemical cues for surface colonization. J. chem. Eco 2002; 28: 1935-1951.

Thakur NL, Anil AC. Antibacterial activity of sponge, Ircinia ramose: Importance of its surface associated bacteria, J. chem. Ecol. 2000; 26 (1): 57-71

Tilvi S, Rodrigues C, Naik CG, Parameswaran PS, Wahidullah S. New bromotyrosine alkaloids from the marine sponge Psammaplysilla purpurea. Tetrahedran 2004; 60: 10207-10215.

Turk T, Frangez R, Sepcic K. Mechanisms of toxicity of 3-Alkalpyridinium polymers from marine sponge Reniera sarai, Mar. Drugs 2007; 5: 157-167.
Wahl M. Mar. Ecol. Prog. Ser. 1989; 58 (1-2): 175-89. Wieczorek SK, Todd CD. Inhibition and facilitation of the settlement of epifaunal marine invertebrate larvae by microbial biofilm cues. Biofouling 1998; 12: 8193.

Williams GB. The effect of extracts of Fucus serratus in promoting the settlement of larvae of Spirorbis borealis (polychaeta). J. Mar. Biol. Ass., U.K 1964; (44): 397-414.

Yebra DM. Kiil S Dam-Johansen K. Review. Antifouling technology - past, present and future steps towards efficient and environmentally friendly antifouling coatings. Prog. Org. coat. 2004; 50: 75104.
Received: Dezembro 06, 2010; Revised: June 06, 2011; Accepted: February 16, 2012. 